Jurnal Geocelebes Vol. 5 No. 1, April 2021, 72 - 79

\title{
KARAKTERISTIK TANAH TEMPAT PENGOLAHAN SAMPAH AKHIR DI KECAMATAN KOTA BANGUN KUTAI KARTANEGARA
}

\author{
Bambang Harimei $^{1 *}$, Muhammad Altin Massinai ${ }^{1}$, Samsu Arif ${ }^{2}$ \\ ${ }^{1}$ Laboratorium Geofisika Padat Departemen Geofisika Fakultas MIPA Universitas Hasanuddin, Makassar \\ 90245, Indonesia \\ ${ }^{2}$ Laboratorium Geoinformatika Departemen Geofisika Fakultas MIPA Universitas Hasanuddin, Makassar \\ 90245, Indonesia \\ *Corresponding author. Email: bambang.harimei@gmail.com
}

Manuscript received: 16 March 2021; Received in revised form: 27 April 2021; Accepted: 30 April 2021

\begin{abstract}
Abstrak
Penelitian ini mengenai karakteristik tanah pada areal perencanaan pengolahan sampah. Metode yang digunakan adalah SPT, CPT dan uji laboratorium. Hasilnya adalah sebagai berikut: ke-empat titik CPT mempunyai nilai Cone Resistance Conus dari kedalaman 1 meter antara $19,78-23,73 \mathrm{~kg} / \mathrm{cm}^{2}$ dan pada kedalaman 4 meter bernilai 201,75-205,68 kg/ $\mathrm{cm}^{2}$. Sedangkan nilai SPT pada kedalaman 1 meter antara 2 - 18 Blows/feet dan pada kedalaman 4 meter nilai $\mathrm{N}$ antara $29-45$ Blows/feet. Uji laboratorium menunjukkan sifat tanah lunak tanah tersebut berwarna, dan batas Atterberg (LL dan PL) makin membesar.
\end{abstract}

Kata Kunci: batas Atterberg; tahanan; tahanan conus.

\begin{abstract}
Research on soil characteristics in the planning area for waste processing. The methods used are SPT, CPT and laboratory tests. The results are as follows: The four points of CPT have a cone resistance conus value from a depth of 1 meter between $19.78-23.73 \mathrm{~kg} / \mathrm{cm}^{2}$ and at a depth of 4 meters between the value of Cone Resistance Conus has a value of $201.75-205.68 \mathrm{~kg} / \mathrm{cm}^{2}$. While the SPT value at a depth of 1 meter between $2-18$ Blows/feet and at a depth of 4 meters $\mathrm{N}$ value between $29-45$ Blows/feet. Laboratory tests showed the soft soil properties of the soil were colored, and the Atterberg limit (LL and PL) was increasing.
\end{abstract}

Keywords: Atterberg Limit; Conus Cone Resistance; resistance.

\section{Pendahuluan}

Tumpukan sampah di jalan poros Kecamatan Kota Bangun dan Ibukota Kabupaten Kutai terlihat berserakan. Pemerintah Kabupaten Kutai memutuskan untuk membangun tempat sampah di Desa Lelong untuk menangani hal itu. Langkah yang telah diambil meneliti karakteristik tanah berlapis, agar pondasi yang digunakan tidak mudah roboh.

Tujuan dari penelitian adalah mengetahui karakteristik tanah melalui parameter resistance cone dalam satuan Blows/feet. Metode yang digunakan Cone Penetration Test (CPT), parameter $\mathrm{N}$ dalam satuan jumlah pukulan palu, digunakan metode 
Standart Penetration Test (SPT), dan parameter Attenberg, butiran dan tekanan trixial metode pengujian laboratorium.

Sampel diberikan kode untuk memudahkan dalam melakukan analisis. Pada uji SPT sampel mempunyai kode $\mathrm{BH} 01, \mathrm{BH} 02$, BH03 dan BH04, sedangkan untuk uji CPT sampel diberikan kode S01, S02, S03 dan S04, pada pengujian laboratorium sampel tidak diberikan kode. Metode pengujian ini telah digunakan (Harimei, 2018).

\section{Metode Penelitian}

Langkah - langkah yang diambil dalam penelitian adalah menentukkan titik koordinat tempat pembuangan sampah, metode yang digunakan dalam menentukan titik koordinat titik koordinat digunakan drone, Bentuk fisik dari lamparan tanah rencana tempat pembuangan tanah luas 16 Ha dan topografi tanah berbukit dengan kemiringan 13 sampai 15\%. Titik koordinat pengambilan Tabel 1. Peta koordinat sampel dan Peta Geologi dapat dilihat dalam Lampiran 3.

Tabel 1. Titik koordinat lokasi penelitian

\begin{tabular}{ccccl}
\hline \multirow{2}{*}{ No } & \multicolumn{2}{c}{ Uji } & \multicolumn{2}{c}{ Titik Koordinat } \\
\cline { 2 - 5 } & CPT & SPT & Northing & Easthing \\
\hline 1 & S01 & BH01 & 0465662 & 9966504 \\
2 & S02 & BH02 & 0465588 & 9966514 \\
3 & S03 & BH03 & 0465711 & 996602 \\
4 & S04 & BH04 & 4657688 & 9966648. \\
\hline
\end{tabular}

Setelah menentukkan titik koordinat langkah selanjutnya melakukan uji sondir atau uji CPT. Uji sondir atau Cone Penetration test (CPT). Pengujian ini bertujuan untuk mengetahui perlawanan penetrasi tekanan konus (tekanan berasal dari ujung tongkat yang ditanjapkan dalam tanah) dan daya geser tanah. Bukan hanya itu, letak lapisan tanah yang keras sekaligus daya dukung serta daya lekat tiap kedalaman perlu diketahui secara spesifik. Setelah hasil tes didapatkan, uji sondir digunakan untuk memenuhi prosedur keselamatan bangunan saat perencanaan daya dukung pondasi terhadap beban bangunan.

Uji sondir merupakan alat yang sederhana dan praktis. Kelebihan uji sondir antara lain; cepat, murah, dan menghasilkan data yang akurat dan detail. Sondir sangat cocok untuk tanah di Indonesia karena kondisi tanah di Indonesia sebagian besar berupa lempung lanauan. Kekurangannya antara lain; Sampel tidak dapat langsung diklasifikasikan sehingga diperlukan uji laboratorium. Pengujian tidak dapat mengetahui batas pelapisan batuan. Lapisan tanah berupa pasir maka alat ini kurang representatif dan tidak dapat menembus lensa gravel/pasir yang cukup tebal dan padat, sehingga bila di bawah lensa pasir terdapat tanah lunak maka sulit untuk terdeteksi. (Hernaningsih, 2010).

Uji CPT merupakan pengujian penetrasi statis. Pengujian ini untuk mendapatkan parameter nilai perlawanan konus/ Conus Resistance, perlawanan geser/ Local Resistance, geseran total/ total resistance, sesuai dengan SNI 2827-2008/ASTM D3441. Setelah didapatkan data dari sampel, berikutnya menghitung Qc dengan mengunakan Persamaan 1:

$$
Q c=\frac{C w \times A p i}{A c}
$$

Qc : Perlawanan konus $\left(\mathrm{kg} / \mathrm{cm}^{2}\right)$

$\mathrm{Cw}$ : Pembacaan manometer untuk nilai perlawanan konus $\left(\mathrm{kg} / \mathrm{cm}^{2}\right)$

Api : Luas penampang piston $\left(\mathrm{kg} / \mathrm{cm}^{2}\right)$

Ac : Luas penampang konus $\left(\mathrm{kg} / \mathrm{cm}^{2}\right)$

Uji SPT bisanya disebut borehole dilaksanakan dengan menggunakan bor mesin yang dimasukkan ke dalam tanah sampai kedalaman tanah yang ditentukan atau sampai jenis kepadatan tanah very hard (N-SPT>50), atau kondisi lapangan tidak bisa lagi dilakukan pengeboran. Pekerjaan boring berfungsi untuk membantu pelaksanaan uji SPT dan pengambilan sampel uji (SNI 
4153:2008/ASTM-D-1586-84(2010)). Uji SPT (Standard Penetration Test) merupakan pengujian penetrasi dinamis. Pengujian ini untuk mendapatkan parameter bor lapisan tanah (bore log exploration) dan jumlah pukulan (N-SPT $=$ Blows/feet) untuk memasukkan 1 feet (12 inchi atau 30,48 cm) dengan memakai suatu beban penumbuk seberat 140 pound $(63,5$ $\mathrm{kg}$ ) yang dijatuhkan dengan ketinggian 30 inchi $(76,2 \mathrm{~cm})$. Pelaksanaan SPT (Standard Penetration Test) dilakukan setiap kedalaman 2 meter, atau sesuai kondisi lapangan (SNI 4153:2008/ASTMD-1586-84(2010)).

SPT adalah suatu metode uji yang dilaksanakan bersamaan dengan pengeboran untuk mengetahui, baik perlawanan dinamik tanah maupun pengambilan contoh terganggu dengan teknik penumbukan. Uji SPT terdiri atas uji pemukulan tabung belah dinding tebal ke dalam tanah, disertai pengukuran jumlah pukulan untuk memasukkan tabung belah sedalam $300 \mathrm{~mm}$ vertikal. Beban jatuh ini digunakan palu dengan berat $63,5 \mathrm{~kg}$, yang dijatuhkan secara berulang dengan tinggi jatuh $0,76 \mathrm{~m}$. Pelaksanaan pengujian dibagi dalam tiga tahap, yaitu berturut-turut setebal $150 \mathrm{~mm}$ untuk masing -masing tahap. Tahap pertama dicatat sebagai dudukan, sementara jumlah pukulan untuk memasukkan tahap ke-dua dan ke-tiga dijumlahkan untuk memperoleh nilai pukulan $\mathrm{N}$ atau perlawanan SPT Sampel tanah dari pemboran dianalisis di laboratorium dan hasilnya dibandingkan dengan parameter tanah yang dihasilkan secara empiris dari hasil tes sondir yang dikaitkan parameter lainnya. Sampel tanah di laboratorium dianalisis untuk mengetahui sifat-sifat dari contoh tanah yang diambil melalui sample tak terganggu (undisturbed) atau terganggu (disturbed). Sifat tanah tersebut meliputi sifat fisis dan sifat mekanis. Metoda yang digunakan dalam pengujian mengikuti standard ASTM D1586 (2010).
Setelah mendapatkan data pengukuran, berikutnya menghitung jumalah pukulan per kedalaman dengan menggunakan persamaan yang dapat dilihat pada Persamaan 2:

$$
N=\frac{\sum_{i=1}^{m} t_{i} x N_{i}}{t_{i}}
$$

Dengan:

$\mathrm{N}$ : Nilai Pukulan rata-rata (Blows/feet)

$\mathrm{t}_{1} \quad$ : Kedalaman (feet).

$\mathrm{N}_{1}$ : Pukulan pada kedalaman (Blows/feet)

Pelaksanaan Uji Laboratorium memiliki hasil penyelidikan antara lain meliputi: Index Physical properties, Natural Water Content ( $\omega)$ (SNI 03-1965-2008), Unit Weight $(\gamma)$ (SNI 03-3637-1994), Specific Gravity (SNI-03-1964-2008), Atterberg Limits (SNI.03-1964-2008), Soil Proportion (SNI 3423-2008/ASTM 42272).

\section{Hasil Dan Pembahasan}

Setelah sampel didapatkan selanjutnya melakukan pengolahan data untuk diketahui Nilai $\mathrm{N}$ dan jenis tanahnya, Rekapitulasi data boring dapat dilihat dalam koordinat lokasi dalam Tabel 1 . Hasil pengukuran di lapangan dapat dilihat dalam Lampiran 2. Kemudian data tersebut diolah dengan menggunakan persamaan 1 . Adapun hasilnya dapat dilihat pada Tabel 2.

Tabel 2. Nilai N dalam Blowes/feet uji SPT.

\begin{tabular}{ccccc}
\hline $\begin{array}{c}\text { Ked. } \\
(\mathrm{m})\end{array}$ & BH01 & BH02 & BH03 & BH04 \\
\hline-2 & 20 & 18 & 21 & 19 \\
-4 & 45 & 27 & 29 & 35 \\
-6 & $>50$ & $>50$ & $>50$ & $>50$ \\
-8 & $>50$ & $>50$ & $>50$ & $>50$ \\
-10 & $>50$ & $>50$ & $>50$ & $>50$ \\
-12 & $>50$ & $>50$ & $>50$ & $>50$ \\
\hline
\end{tabular}

Tabel 2 mempelihatkan hasil pengujian pada sampel $\mathrm{BH} 01, \mathrm{BH} 02, \mathrm{BH} 03$ dan BH04. Hasil uji BH01 kedalaman 0,00 1,00 meter nilai $\mathrm{N}$ sebesar $5-10$ 
Blows/feet, material yang terkandung lempung kelanauan berwarna kuning kecolakan dengan ketebalan 0,5 meter.

Kedalaman antara $1-2$ mater terdapat lempung dengan sifat fisik kaku dan berwarna kuning kecoklatan. Nilai N $10-$ 20 Blows/feet.

Kedalaman 2- 6 meter terdapat lempung dengan sifat fisik kaku, ketebalan sampel 1 meter warna kecoklatan.

Kedalaman $8-12$ meter terdapat batuan lempung dengan sifat fisik kaku, warna pekat kecoklatan, nilai $\mathrm{N}$ sebesar 50 Blows/feet.

Selanjutnya, diperoleh hasil pengujian CPT pada titik sampel S01, S02, S03 dan S04. Hasil pengukuran di lapangan dapat dilihat dalam lampiran 1 , kemudian diolah dengan persamaan 2. Adapun hasil dari pengolahan dapat dilihat dalam Tabel 3.

Tabel 3. Rekapitulasi hasil Uji Sondir.

\begin{tabular}{ccc}
\hline Titik & $\begin{array}{c}\text { Kedalaman } \\
(\mathrm{m})\end{array}$ & $\begin{array}{c}\text { Cone Resistance } \\
\left(\mathrm{Kg} / \mathrm{cm}^{2}\right)\end{array}$ \\
\hline \multirow{3}{*}{$\mathrm{S} 01$} & 1 & 32,63 \\
& 3 & 79,11 \\
& 4,8 & 201,73 \\
$\mathrm{~S} 02$ & 1,00 & 19,78 \\
& 5,00 & 108,77 \\
& 6,40 & 202,72 \\
\hline & 1,00 & 23,73 \\
$\mathrm{~S} 03$ & 3.00 & 89,00 \\
& 4,20 & 204,69 \\
\hline & 1,00 & 23,73 \\
$\mathrm{~S} 04$ & 3.00 & 79,11 \\
& 4,40 & 205,68 \\
\hline
\end{tabular}

Tabel 3. memperlihatkan hasil pada pengambilan data pada titik Sondir S01, S02, S03 dan S04. Jenis kepadatan tanah Keras/ hard didapatkan sampai pada kedalaman 4,80 $\mathrm{m}$ (nilai cone resistance $=$ $201.73 \mathrm{~kg} / \mathrm{cm}^{2}$ ). Setelah dikonfirmasikan dengan tabel dalam Terzaghi dan Peck (1948) didapatkan konsistensi tanah hasil pengujian di lapangan beberapa jenis kepadatan yaitu: jenis kepadatan tanah "very soft" dengan nilai konus $(0-10$ $\mathrm{kg} / \mathrm{cm}^{2}$ ) berada pada kedalaman $0,00-0,30$ $\mathrm{m}$. Jenis kepadatan tanah "soft" dengan nilai konus $\left(10-20 \mathrm{~kg} / \mathrm{cm}^{2}\right)$ berada pada kedalaman 0,30-0,70 m. Jenis kepadatan tanah "medium" dengan nilai konus (20 $40 \mathrm{~kg} / \mathrm{cm}^{2}$ ) berada pada kedalaman 0,70 $1,50 \mathrm{~m}$. Jenis kepadatan tanah "stiff" dengan nilai konus $\left(40-75 \mathrm{~kg} / \mathrm{cm}^{2}\right)$ berada pada kedalaman 1,50 - 2,90 m. Jenis kepadatan tanah "very stiff" dengan nilai konus $\left(75-150 \mathrm{~kg} / \mathrm{cm}^{2}\right)$ berada pada kedalaman 2,90-4,30 m. Jenis kepadatan tanah "hard" dengan nilai konus (>150 $\mathrm{kg} / \mathrm{cm}^{2}$ ) berada pada kedalaman 4,30-4,80 $\mathrm{m}$. Hasil langsung di lapangan dapat dilihat dalam Lampiran 2.

Langkah ke-tiga dalam penelitian tanah yaitu mengambil sampel untuk diuji di laboratorium. Adapun hasil uji laboratorium dapat dilihat pada Tabel 4.

Tabel 4. Hasil Uji Laboratorium

\begin{tabular}{|c|c|c|c|}
\hline Uji & $\begin{array}{l}\text { Simbol } \\
\text { satuan }\end{array}$ & $\begin{array}{c}\text { Kedalaman } \\
(\mathrm{m}) \\
0,5-1,5\end{array}$ & $\begin{array}{c}\text { Kedalaman } \\
\text { (m) } \\
1,5-4,5\end{array}$ \\
\hline \multirow{4}{*}{$\begin{array}{c}\text { Index } \\
\text { Properties }\end{array}$} & $\mathrm{w} \%$ & 30.464 & 40.322 \\
\hline & $\Gamma \mathrm{t} / \mathrm{m}^{3}$ & 1,708 & 1,949 \\
\hline & $\mathrm{E}$ & 1,217 & 1,466 \\
\hline & Gs & 2,655 & 2,688 \\
\hline \multirow{3}{*}{ Atterberg } & LL \% & 26,93 & 47,80 \\
\hline & PL \% & 19,60 & 26,42 \\
\hline & PI \% & 7,33 & 21,38 \\
\hline \multirow{4}{*}{ Butiran } & $\mathrm{Kr} \%$ & 1 & 1 \\
\hline & Ps $\%$ & 10 & 10 \\
\hline & $\begin{array}{c}\text { Lanau } \\
\%\end{array}$ & 93,67 & 90,49 \\
\hline & $\begin{array}{c}\text { Clay } \\
\%\end{array}$ & 70,05 & 76,54 \\
\hline Triaxial & $\begin{array}{c}\mathrm{C} \\
\mathrm{kg} / \mathrm{cm}^{2}\end{array}$ & 0,15 & 0,17 \\
\hline \multirow{3}{*}{ Consol } & $\mathrm{Cc}$ & 0,76 & 1,12 \\
\hline & $\begin{array}{c}\mathrm{Pc} \\
\mathrm{kg} / \mathrm{cm}^{2}\end{array}$ & 1,65 & 1,78 \\
\hline & $\begin{array}{c}\mathrm{CV} \\
\mathrm{cm}^{2} / \mathrm{s}\end{array}$ & $0,68 \times 10^{-3}$ & $0,96 \times 10^{-3}$ \\
\hline
\end{tabular}

Hasil uji sampel di laboratorium: kadar air berkisar antara 17,65 - 58,73\% dengan rata-rata $41,15 \%$. Kondisi batas plastis dan 
elastis berkisar antara 94,62 - 99,93\% dengan rata-rata $97,28 \%$.

Jenis tanah lapisan permukaan pada titik bor sampai kedalaman $3,50 \mathrm{~m}$ berjenis lanau dengan persentase antara $55-60 \%$ dengan rata-rata $57,50 \%$, lempung 20,50 $\%$. Berikutnya hasil ketiga metode di-plot untuk menentukkan kedalaman tanah keras. Nilai JHL pada kedalaman 1 meter rata-rata $35,45 \mathrm{~kg} / \mathrm{cm}$. Pada kedalaman 4 meter JHL sebesar 634,42-908,23 kg/cm. Sifat tanah kedalaman 4 meter: kadar air asli tanah di lapangan berkisar pada nilai rata-rata $41,15 \%$ dan tanah dalam kondisi pada batas plastis mendekati batas cair (liquid limit) dengan nilai rata-rata 97,28 $\%$. Jenis tanah lapisan permukaan pada titik bor sampai dikedalaman $3,50 \mathrm{~m}$ merupakan jenis lanau dengan persentase antara rata-rata $57,50 \%$ dan lempung dengan persentase rata-rata $20,50 \%$.

Hasil dari pengujian CPT, SPT dan laboratorim dapat dilihat dalam Gambar 2. Pada kedalaman tanah mulai 0,5 sampai 2 meter bersifat lunak karena berisi lempung kelanauan, dari kedalaman 2 meter sampai kedalaman 3,5 meter tanah mulai bersifat keras. Tanah makin keras saat kedalaman 4 meter. Pada kedalaman 4 meter lebih tanah makin keras.

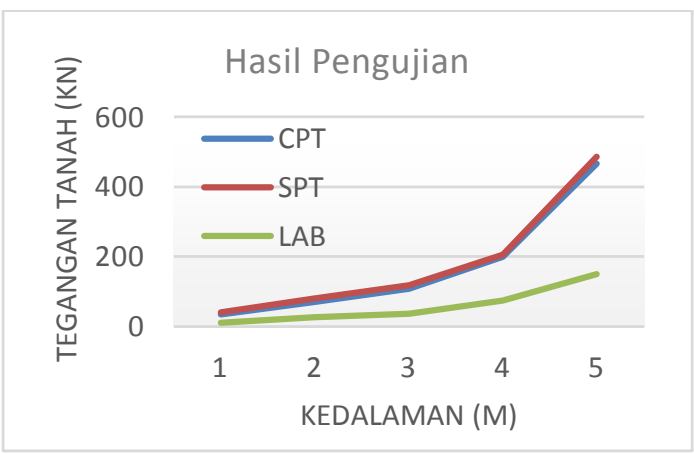

Gambar 1. Hasil ketiga metode pengujian.

\section{Pembahasan}

Adapun hasil nilai SPT, CPT dan laboratoium makin meningkat. Hasil pengujian bor, sondir dan hasil uji laboratorium pada tanah cenderung naik. Ke-empat titik CPT mempunyai nilai Cone
Resistance Conus dari kedalaman 1 meter rata-rata $20,73 \mathrm{~kg} / \mathrm{cm}^{2}$ dan pada kedalaman 4 meter nilai Cone Resistance Conus mempunyai nilai rata-rata $202,14 \mathrm{~kg} / \mathrm{cm}^{2}$.

\section{Kesimpulan}

Ke-empat titik CPT mempunyai nilai Cone Resistance Conus dari kedalaman 1 meter antara $19,78-23,73 \mathrm{~kg} / \mathrm{cm}^{2}$ dan pada kedalaman 4 meter nilai Cone Resistance Conus mempunyai nilai 201,75 - 205,68 $\mathrm{kg} / \mathrm{cm}^{2}$. Sedangkan nilai SPT pada kedalaman 1 meter antara $2-18$ Blows/feet dan pada kedalaman 4 meter nilai $\mathrm{N}$ antara 29 - 45 Blows/feet. Uji laboratorium menunjukkan sifat tanah lunak, tanah tersebut berwarna, dan batas Atterberg (LL dan PL) makin membesar.

\section{Daftar Pustaka}

ASTM D1586 / D1586M - 18. 2010. Standard Test Method for Standard Penetration Test (SPT) and SplitBarrel Sampling of Soils. Annual Book of ASTM (America Standard Test Method) Internasional. [Online]. Available from: https://www.astm.org/Standards/D 1586.htm

Harimei, B. 2018. Analisis Tanah Pada Perencanaan Prasarana Umum. Jurnal Geocelebes, 2(1), pp.42-46. https://doi.org/10.20956/geocelebes . $\mathrm{v} 2 \mathrm{i} 1.3993$

Hernaningsih, T. 2010. Penelitian Tanah sebagai Pendukung Pengembangan Instalasi Pengolahan Limbah Cair Domestik di Kantor BPP Teknologi. Jurnal Air Indonesia, 6(1), pp. 94102.

https://doi.org/10.29122/jai.v6i1.24 $\underline{59}$

Terzaghi, K. dan Peck, R.B. 1948. Soil Mechanic in Engineering Practice. New York: John Wiley \& Sons; London: Chapman \& Hall. 


\section{Lampiran 1: Data Lapangan Cone Penetration Test (CPT)}

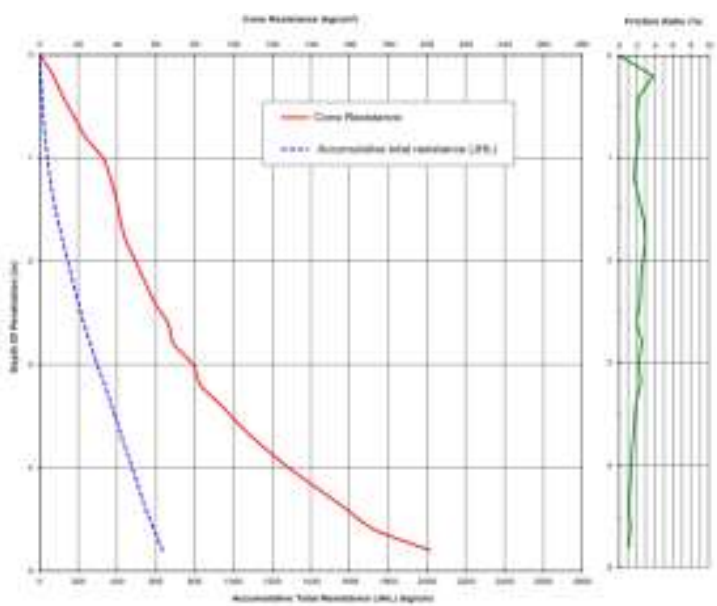

Lampiran 1a. Titik Sondir S01

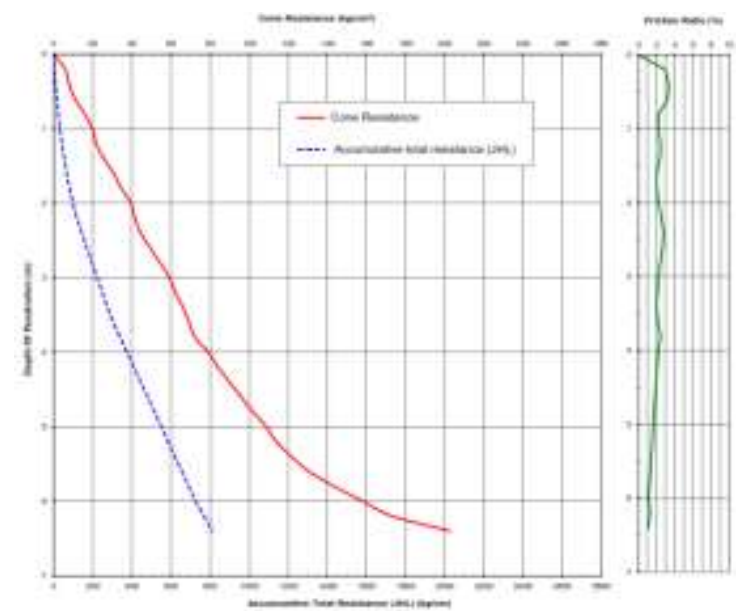

Lampiran 1b. Titik Sondir S02

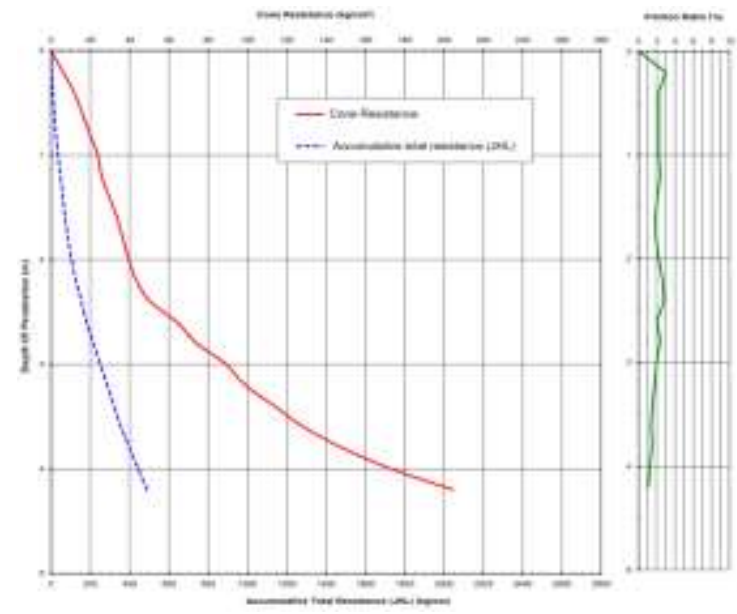

Lampiran 1c. Titik Sondir S03

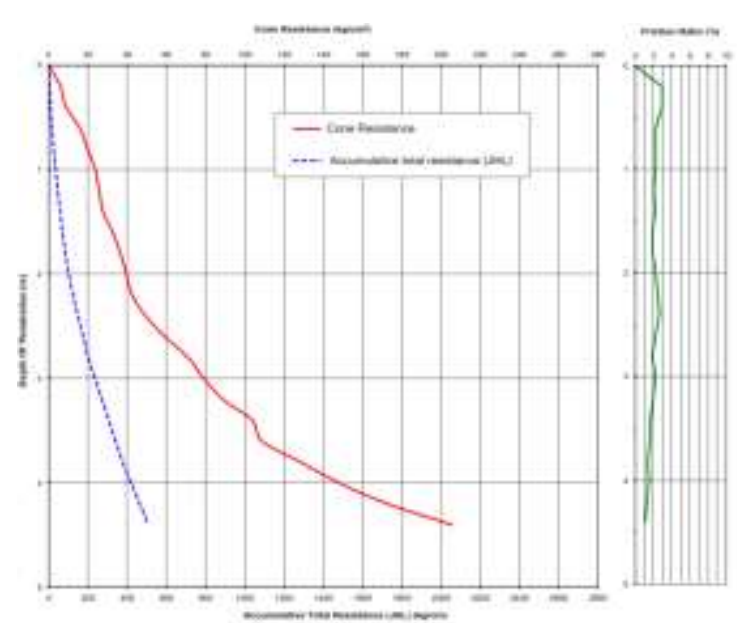

Lampiran 1d. Titik Sondir S04 
Karakteristik Tanah Tempat Pengolahan Sampah Akhir ...

Lampiran 2: Data Lapangan Standart Penetration Test (SPT).

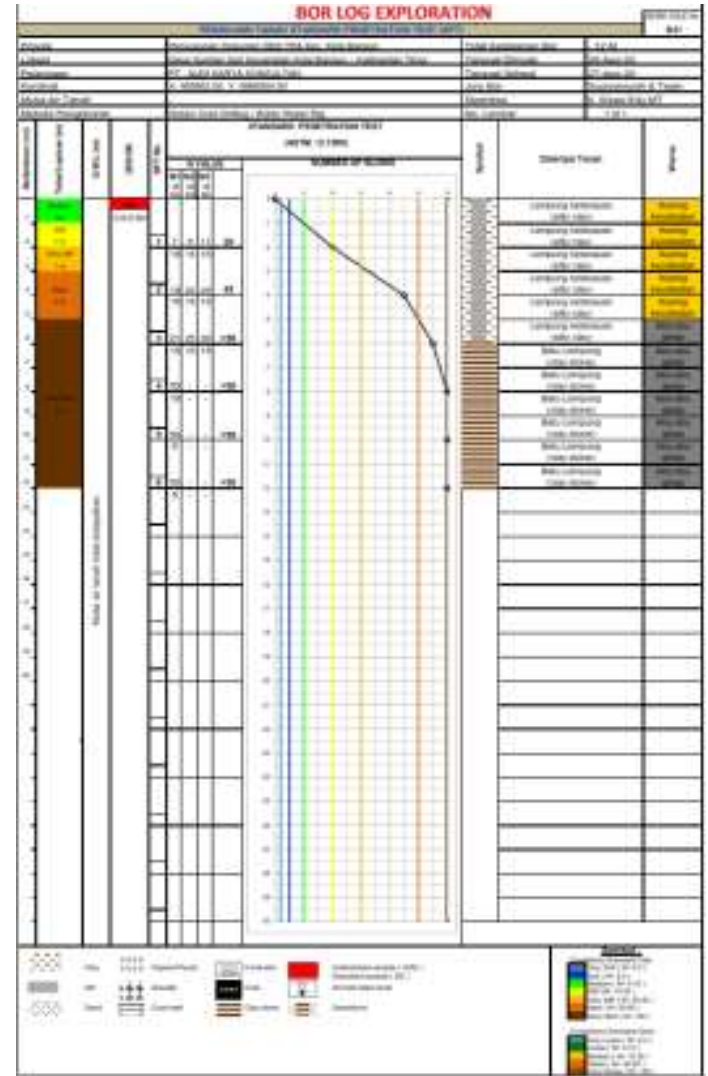

Lampiran 2a. Titik Bor BH01

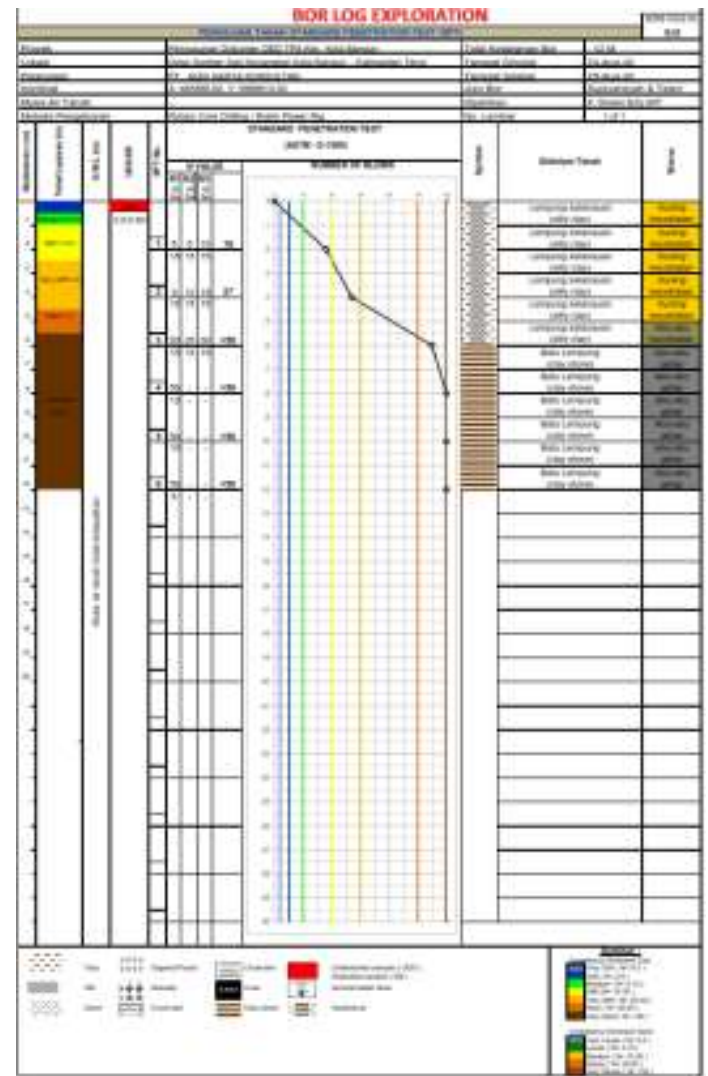

Lampiran 2b. Titik Bor BH02

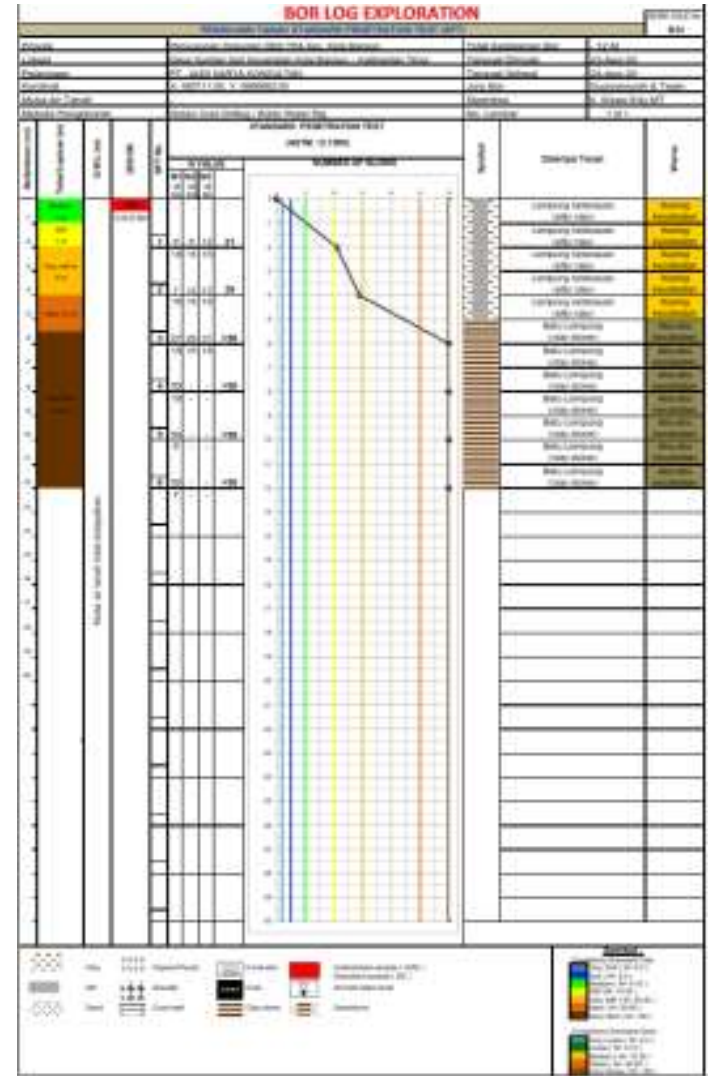

Lampiran 2c. Titik Bor BH03

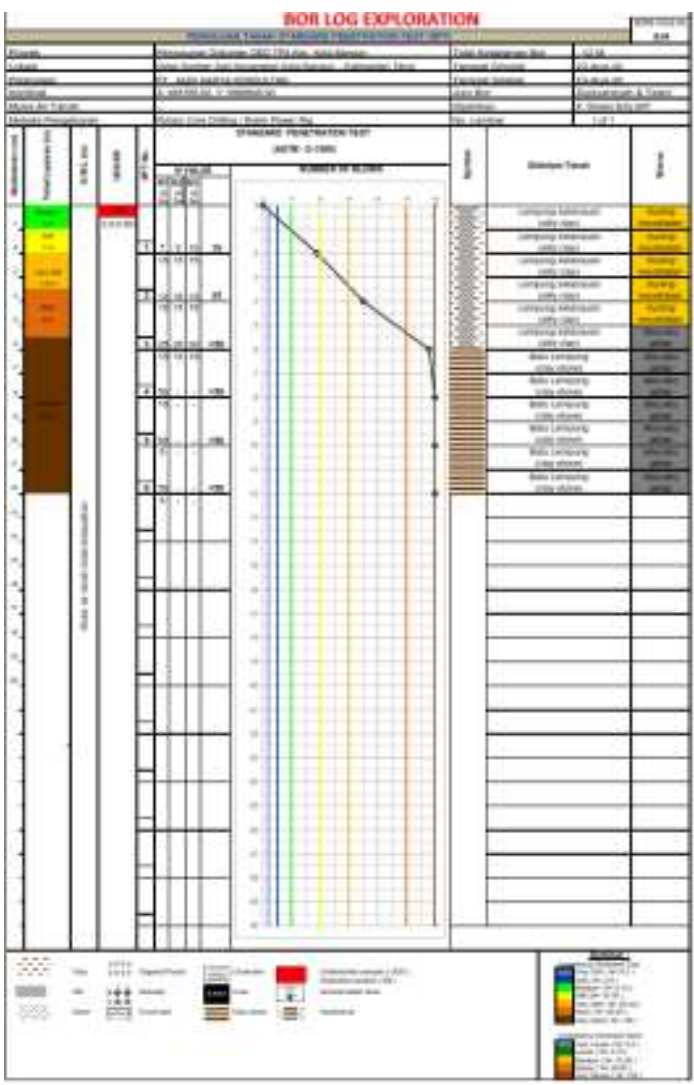

Lampiran 2d. Titik Bor BH04 
Lampiran 3a: Peta Geologi Lokasi Penelitian

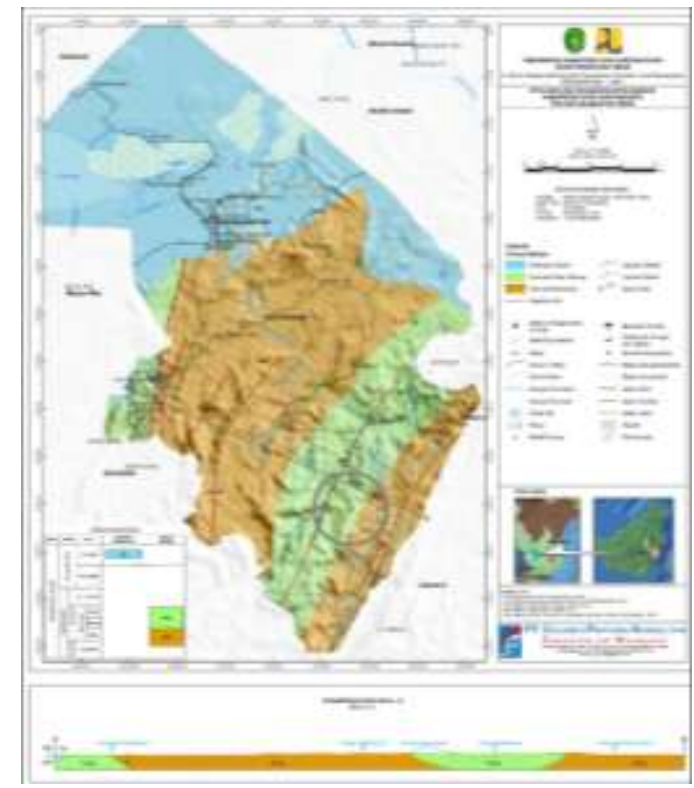

Lampiran 3a. Peta Geologi Lokasi Penelitian
Lampiran 3b: Titik Pengambilan Sampel

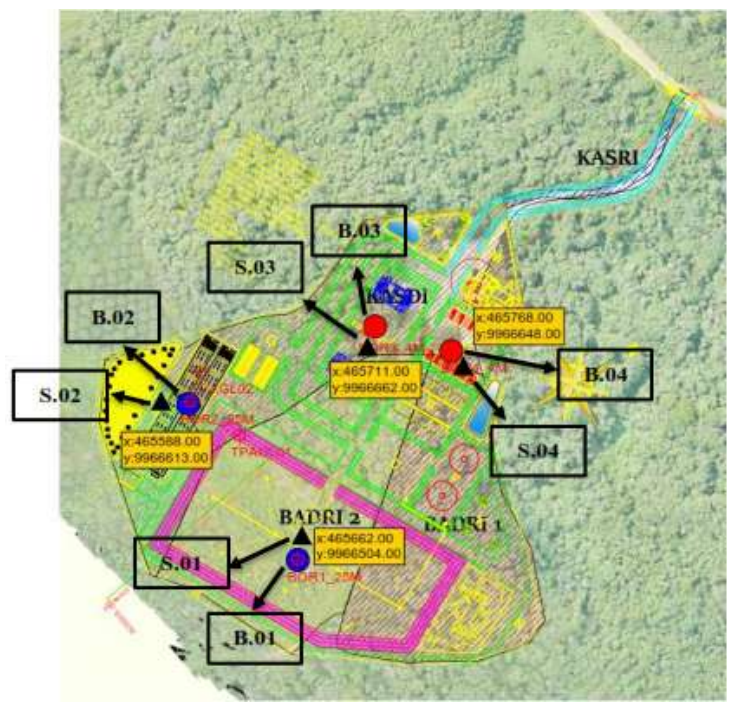

Lampiran 3b. Titik Koordinat Pengambilan Sampel 